\title{
Social movements, class, and adult education
}

\author{
Shirley Walters
}

Social movements are movements of people in civil society who cohere around issues and identities that they themselves define as significant (Martin, 1999). The following quotation describes a group of poor women in South Africa, a group calling itself People's Dialogue, who are mobilizing around their need for houses. They are part of a social movement of women and men internationally who are collectively struggling for access to land and houses.

Women are singing Ululating, dancing, Marching Carrying placards for their different housing associations, Wearing T shirts which readPeople's Dialogue for Housing and Shelter We Want! Power! Money! Knowledge!

The songs they sing tell of the hardships they endure in the shacks, the threat from fire, rain and the wind from eviction even under a new government.

Now they have started to build houses by saving R2 [two South African rands (equivalent to 35 U.S. cents)] a day.

These women are marching to the mass meeting in Hout Bay settlement, Imizamo Yethu. The atmosphere is electric, there is lots of energy, excitement and anxiety as the different housing savings groups take the courage to say enough is enough, we are tired of this kind of life, and don't want to die in fires any longer and they say, 'We work with all our hearts to do the good work and do not want to be pitied and we will rebuild our lives as we build our homes"” (Ismail, 2003, p. 94).

The fact that the women from People's Dialogue are poor, they speak IsiXhosa, and they are women shapes very much what they do and how they do it. This chapter will examine how particularly notions of class affect the education in and the learning fostered by social movements. I will begin with a discussion of what social movements are and what adult education and learning means in relation to them. I will then focus in on South African social movements as a "mirror and lens" (Crowther, Martin, and Shaw, 1999, p. 2) in order to draw out key issues. In this era of globalization, South Africa is a 
microcosm of wider processes at work in other societies. It is a middle-income country that has recently emerged from a protracted liberation struggle; and its reentry into the global economy is heightening the tensions between economic development, equity, and redress. As such, South Africa is both a mirror reflecting these processes and a lens through which to examine them.

\section{What Are Social Movements?}

Social movements are voluntary associations of people and organizations within civil society that rise and fall in response to particular social, economic, ideological, and political changes and issues often driven by the state or the market. They are reactive and are sustained by their relationships to the particular issues or circumstances. A common feature of much social-movement activity is its oppositional or alternative nature. Social movements are the lightning rods of society. They can be either conservative reactionary forces or progressive. The focus in this chapter is on the latter.

Welton (quoted in Martin, 1999) identifies three general characteristics of social movements: they articulate a collective identity, which means that their members subscribe to a common cause that the movement expresses collectively; they exist in an antagonistic relation to an opposed group or interest; they have a normative orientation, which means that they embody a mobilizing ethic, moral code, or set of beliefs that reflect shared values and purposes.

Social movements have a long history around the world, for example, within anticolonial struggles, among peasants and workers, the urban poor, black people, and women. Oppressed and exploited people have fought back against their harsh material realities through collective organizing. Many social movements have historically organized around class-related issues. Eyerman and Jamison (1991, p. 62) say that social movements are "at once conditioned by the historical contexts in which they emerge, their particular time and place, and, in turn, affect that context through their cognitive and political praxis." To understand the workings of particular social movements, you therefore have to locate them quite particularly.

Melucci (quoted in Badat, 1999, p. 29) argues that we should see social movements as "action systems operating in a systemic field of possibilities and limits. . . . Social movements are action systems in that they have structures: the unity and continuity of action would not be possible without integration and interdependence of individuals and groups." In many instances a social movement comprises various smaller interdependent organizational structures, working toward a particular social goal. The social movement in turn may well form a coalition with other social movements, in order to create a united front to oppose an issue or promote an idea.

Through participation in social movements, people prepare for change or resistance to it by challenging or confirming the ways in which they think and feel and act politically. Their moral or counterhegemonic work may become the common sense of an era. As Martin 
(1999, p. 10) states, "in this sense social movements are intrinsically educative both for the participants and for the broader society."

\section{Social-Movement Learning}

Eyerman and Jamison (1991) have made a seminal contribution to understanding learning in social movements. They state (p. 14): "Social move ments are not merely social dramas; they are the social action from where new knowledge including worldviews, ideologies, religions, and scientific theories originate." Because adult education is integral to social processes and therefore social movements, it is not surprising that it gains in prominence at heightened political or economic moments in response to actions within the state, civil society, or the private sector.

Social-movement learning includes both learning by people who participate in social movements and learning by people outside of social movements through the impact they make (Hall and Clover, 2005). Learning through a movement can occur informally through participation or through intentional educational interventions. The educational and organizational practices intertwine. The cultural, gender, class, and ethnic locations of the individuals or groups involved shape the educational and organizational practices, just as they are shaped by the particular historical conjuncture. Social movements are exceedingly rich learning environments. So in those movements organized around class-related issues such as working conditions, housing, health, and other social services, participants come to realize that collective action and solidarity, as captured in the workers' slogan "an injury to one is an injury to all," is the most effective approach to overcome social and economic hardships.

I turn now to explore what these ideas mean in a specific context through a description of social movements in South Africa, with a particular focus on the ways that social class shapes organizational and educational practices.

\section{Social Movements in South Africa}

Over the last hundred years in South Africa, civil society has responded to political, social, cultural, and economic hardships through mobilizing people across social class, ethnicity, gender, and geography into social movements. During the 1970s, 1980s, and early 1990s, the political social movements for democracy were particularly prominent. These movements adopted innovative organizational and educational processes to encourage women and men of all classes and racial categories to participate actively in the movement for change. In 1994 national liberation was achieved. More recently social movements have again formed in response to economic and social hardships in relation to land and privatization of basic services (like water), HIV/AIDS, and violence against women and children; some have strong links to international social movements. Each of the social movements has a different composition of membership depending on its social purposes. Some, for example, are rooted very particularly among the land-less and the poor, others among middle-class, working-class, and poor women. The composition of movements shapes profoundly the organizational and educational activities within them. I will draw on a study (Walters, 1989) of self-education within the social movements in the 1980s, 
which shows this clearly.

The history of resistance in South Africa from the early twentieth century involves a complex interplay between national political organizations and social-movement struggles; Abrahams (1996) provides a succinct description of this. The socialmovement struggles have had a significant effect on the development of strategic perspectives of political organizations. When the African National Congress (ANC) was formed in 1912, it reflected an attempt to unite people, who until then had resisted colonialism in scattered and disparate ways, into a national political movement. The development of capitalism in South Africa in the latter half of the nineteenth century had destroyed the traditional precapitalist social formations of the indigenous people. The political, social, and economic institutions that emerged during those early years gave the South African social formation its peculiar racial capitalist character. The early national liberation movement, mainly made up of the ANC, whose leadership came almost entirely from the ranks for the emergent African middle class, had no mass membership and in many ways represented the social and political outlook of that social class. As Abrahams argues, this outlook sharply circumscribed the political strategies and tactics the ANC advocated and employed.

In mass protests women resisted an attempt to extend the notorious pass laws to them, forcing the state to drop the idea temporarily. (Pass laws prescribed who could enter, live, and work in certain areas. The common result was that black men and women had to carry a pass on them at all times or face punishment and imprisonment.) The conservative ANC leadership was forced to respond to social-movement struggles engineered and led by people in communities and in the mines. The Communist Party of South Africa, formed in 1921, provided a very important theoretical input that helped shape the early perspectives of the nascent liberation movement. One of the factors that made class alliances possible was a shared oppression that all black people in South Africa experienced.

In the early 1940s, numerous social movements of the poor emerged in response to people's worsening economic, social, and political positions. The enormously exploitative conditions that oiled the wheels of white capitalism meant that issues such as housing, cost of living, fuel, transport, and clothing all became highly contentious political issues for black people. Numerous grassroots social movements emerged in the urban slums, arising out of local frustrations at appalling conditions. Their emerging leadership was not of the same social class or outlook as that of the existing political organizations. However, they began processes that effectively pushed organizations like the ANC toward the left. Such social movements were defensive responses by the working class and poor to socioeconomic crises. They tended to have short life spans. The ANC began to provide the glue to bond them into a sustainable movement to end white minority rule, a movement that conformed to the three characteristics of social movements that Welton (quoted in Martin, 1999) identified: a collective identity of oppressed people, an antagonistic relationship with the white minority government, and a vision of a nonracial democratic 
state.

In this early period, the impact of poor and working-class people on the shape and form of the liberation movement was marked. They influenced what the movement took up and how. Evidence of this influence was visible in the 1950s when the ANC changed into a mass-based organization that adopted strikes, boycotts, mass protests, and general civil disobedience as its new weapons. Seeking the destruction of white minority rule necessitated creation of the broadest front of resistance because it affected people across class, social, and racial lines. It thus laid the basis for the potential unity of those social forces and classes. Among the white people were also those prepared to throw in their lot with the oppressed in pursuit of nonracial democracy.

The 1960 s was a quiet period because the state had banned political organizations and jailed their leadership. The ANC set itself up in exile and established its military wing. The social movements of the 1970 s and 1980 s can be traced back to these earlier periods. As Melucci (quoted in Badat, 1999, p. 32) states, it is important to recognize the relationship between the visible and latent dimensions of collective action: during the latency phase, "the potential for resistance or opposition is sewn into the very fabric of daily life. It is located in the molecular experience of the individuals and groups who practice the alternative meanings of everyday life. Within this context, resistance is not expressed in collective forms of conflictual mobilizations. Specific circumstances are necessary for opposition and therefore of mobilizing and making visible this latent potential." Thus, phases of latency, far from being periods of inaction, are crucial to the formation and development of abilities and capacities for mobilization and struggle.

The formation of the United Democratic Front (UDF) in 1983 was a culminating point of the reemergence of popular struggles in the $1970 \mathrm{~s}$ and responses to the state's restructuring. The UDF comprised thousands of sector organizations nationally. Two of the most significant social-movement formations within the UDF were the trade union movement and community-based residents' associations that formed around specific issues. The independent trade union movement was emphasizing the importance of worker democracy within the unions and the workplace as an essential part of the broader struggle for democracy; this movement did not join the UDF until later. Its participants saw community organizations as unaccountable and were at times critical of middle-class leadership.

Through the collective struggles with community organizations, the differences between the forms and functions of trade unions and other organizations came into focus. The unions initially argued against affiliation to the UDF because they saw the different class composition of the various affiliates as leading to different possibilities for organizational forms and strategies. There were ideological struggles in the unions themselves between those who emphasized organizing in the workplace and those who argued for closer worker-community solidarity. Harsh repression from the state forced closer work among and across organizations. 
Besides differences across class and organizational forms, racial differences intersected with class. Within the apartheid hierarchy, the African townships were the most impoverished; and Webster (in Walters, 1989) found that the working class and the poor devised all sorts of strategies to cope with their poverty and oppression. Many people were engaged in informal sector activities such as brewing beer and hawking food, and they fleshed out their inadequate income through small self-help groups like burial societies and credit societies. They were defensive responses. Molefe (quoted in Walters, 1989, p. 120) found that it was more difficult in African areas to establish more structured community organizations: "We see less of a natural drift towards committees or formal styles of organizations." He comments on the lower levels of repression in the Indian and Coloured areas than in African areas. (The racial hierarchy privileged white, then Indian, then Coloured, then black Africans. This meant that residential areas reflected the degree of privilege and deprivation in that order.) Organizations were therefore less vulnerable. The level of repression also forced many Africans to believe that the only viable option was a military one. Thus, the repression aided recruitment for the liberation army rather than for small-scale relatively reformist community struggles. Molefe's third point was that the greater degree of material deprivation created organizational possibilities. There were limited resources for people to draw on. People who had overcome the struggle for survival had more time and inclination to engage in other struggles. These realities played out in the ways that organizations operated. For example, in African townships people were mobilized mainly through mass meetings; in Coloured areas there was more door-to-door organizing. The symbolic and cultural forms that organizations used also varied across ethnic groups. Singing, dancing, and ululating were integral to African-led organizations, as we see in the opening quotation.

Within organizations like the United Women's Organisation, an important affiliate of the UDF, the class and cultural alliances among women were significant. The organization was formed into branches based in geographical areas in Cape Town. Because of the ecology of the apartheid city, this meant that each of the branches adopted a distinctive profile in terms of racial, language, and class differences. The older African women and some Coloured women, who had status from their close involvement with the liberation movement, provided the political leadership. The white middle-class women played a support role, although each branch had the autonomy to shape its own activities. So the participants' biographies influence particular branches' activities. For example, one branch of mainly white women did a popular history project to highlight the devastating effects of the Group Areas Act, while an African branch organized a march to the local shop against hikes in bread prices. The white women, because of their privileged class positions, were able to provide transport and other organizational infrastructure to support organizing in the poor working-class areas.

Learning within the social movements was conscious. Most of the affiliated organizations promoted participatory democratic practices as a way of building members' capacities. Originating in the Black Consciousness Movement was the imperative for black people to

\section{http://repository.uwc.ac.za}


gain confidence and capacity to lead. Within the nascent women's movement was the commitment to develop women, particularly black working-class women. In the trade unions was the need to build worker leadership. The emphasis was on collective leadership and learning by doing. However, as Walters (1989) describes in great detail, the participatory democratic practices were shaped by the origins and purposes of the organization, the members' biographies, and members' theoretical understandings of their actions. Those who were most closely allied to the movement in exile had stronger accountability to that; whereas others emphasized the importance of the collective inside the country, township, or organization. The tensions between accountability to the collective within one affiliate and to the broader movements, both inside the country and in exile, were palpable. These often had racial, class, and other historical dimensions.

The influence of ideologies and philosophies from international social movements on the ways of organizing was also apparent. The works of the Italian Marxist Gramsci and Brazilian Freire, among others, were widely read. The radical students, worker, women's, and black movements in North America and Europe were also influential, as were the anticolonial struggles in Africa.

The contemporary social movements in South Africa are influenced by the intense social mobilizing of the earlier years of struggle. There are both continuities and breaks with the past. As Ismail (2003, p. 100) describes the women of the South African Homeless People's Federation, "They sing various hymns, slogans, traditional songs, which they often combine with protest songs from the struggle days, and new protest songs from the Federation. They sing about the hardship of being in shacks that are prone to rain and evictions." What is new is that they have strong relationships internationally as they build "globalization from below" (Marshall, 1997, p. 57). They have, for example, special relations with the National Slum Dwellers Federation in India, and their education has been enriched through exchange programs with them. The people's development strategies resonate with working-class and poor women's pedagogy in other parts of the world (Walters and Manicom, 1996; Foley, 1999). Although the hegemony of the neoliberal global economy ensures that the struggles continue for poor and working-class women and men in South Africa, they are reacting in new and creative ways.

\section{In Closing}

Social movements are privileged locations for the creation of new knowledge. They are, as Eyerman and Jamison (1991, p. 10) have said, "epistemic communities." They stress the historical and social construction of ideas and the active role that social movements play in knowledge production. Cognitive praxis, they argue, "does not come ready-made to a social movement. It is precisely in the creation, articulation, formulation of new thoughts and ideas-new knowledge-that a social movement defines itself in society" (p. 10). Knowledge is produced through debates over meeting agendas, the planning of meetings, campaigns and demonstrations, and exchanges over strategies and tactics. It is also generated, as Badat (1999) argues, in interaction with old movements, old traditions, concepts, and values and in the recombination and reinterpretation of intellectual roles 
and practices. The South African social movements through action over many years generated the hope and possibility of a new democratic, nonracial, and nonsexist order.

As we have seen, the social movements were molded within the particular historical conjunctures. The alliances across class, ethnicity, gender, and race forged organizational and educational practices. The setting of the agenda of the movements over time was shaped very directly by the economic conditions of the poor. They challenged the middleclass leadership of the ANC in the 1930s and 1940 s and influenced directly what the movements did and how they operated. In the 1970 s and 1980s, the organized working class strongly influenced what and how movements organized, but other working-class and poor people organizing in their localities contested this. Contestations among workingclass and middle-class leadership were also reality. Old and new cultural forms shaped the movements' symbolic and expressive moments.

It is not possible to isolate the influence of class alone on the pedagogy and politics of social movements because class is so intertwined with other social categories. However, the social locations of the members and their relative degrees of wealth or poverty will, of course, have profound effects on their consciousness, which will shape what issues they take up and in whose interests they mobilize. For example, in the environmental movements in various parts of the world, there is at times deep difference of opinion between communities of environmental activists, depending on their socioeconomic circumstances. Some indigenous communities struggling for survival have sometimes asked whether an endangered animal is more significant than their endangered community. So for adult educators and activists, this discussion on class and social movements raises several key questions:

- How is the mode of organizing within social movements going to encourage or inhibit people of different economic and social backgrounds from participating?

- Who is giving leadership? What are their socioeconomic circumstances? And how will this shape what issues the movement takes up when and where?

- What is the different cultural, ethnic, gender, and class mix of the social movement? How can the movement give expression to the range of cultural practices among women and men in order to maximize their participation?

- What are the historical class-related traditions within particular social movements that participants can build on?

- How does my own social and economic class position influence my own practices as adult educator and activist? 


\section{References}

Abrahams, D. "South Africa: Social Movements, Coalitions, and the Struggle for Democracy." In Philippines-Canada Human Resource Development Program, From Resistance to Transformation: Coalition Struggles in Canada, South Africa, the Philippines and Mexico. Ontario: Philippines-Canada Human Resource Development Program, 1996. Badat, S. Black Student Politics, Higher Education and Apartheid: From SASO to SANSCO, 1968-1990. Pretoria: HSRC, 1999.

Crowther, J., Martin, I., and Shaw, M. (eds.). Popular Education and Social Movements in Scotland Today. Leicester, England: National Institute of Adult Continuing Education, 1999.

Eyerman, R., and Jamison, A. Social Movements: A Cognitive Approach. Oxford: Polity Press, 1991.

Foley, G. Learning in Social Action: A Contribution to Understanding Informal Education. London: ZED Books, 1999.

Hall, B., and Clover, D. "Social Movement Learning." In L. English (ed.), International Encyclopedia of Adult Education. London: Palgrave Macmillan, 2005.

Ismail, S. “A Poor Woman's Pedagogy.” Women's Studies Quarterly, 2003, 31(3/4), 94112.

Marshall, J. "Globalization from Below: Trade Union Connections." In S. Walters (ed.), Globalization, Adult Education and Training: Impacts and Issues. London: ZED Books, 1997.

Martin, I. "Introductory Essay: Popular Education and Social Movements in Scotland Today." In J. Crowther, I. Martin, and M. Shaw (eds.), Popular Education and Social Movements in Scotland Today. Leicester, England: National Institute of Adult Continuing Education, 1999.

Walters, S. Education for Democratic Participation. Bellville, South Africa: University of the Western Cape, 1989.

Walters, S., and Manicom, L. Gender in Popular Education. Methods for Empowerment. London: ZED Books, 1996. 